\title{
Do non-native pumpkinseed Lepomis gibbosus affect the growth, diet and trophic niche breadth of native brown trout Salmo trutta?
}

\author{
M. C. Jackson · J. R. Britton • J. Cucherousset - Z. Guo • \\ S. Stakènas • R. E. Gozlan - M. G. Godard · J.-M. Roussel • \\ G. H. Copp
}

Received: 23 April 2015/Revised: 4 January 2016/Accepted: 5 January 2016/Published online: 19 February 2016

(C) The Author(s) 2016. This article is published with open access at Springerlink.com

\begin{abstract}
Brown trout Salmo trutta Linnaeus, 1758, is a priority species for conservation and management efforts in many European countries. In its native range, interactions with non-native fishes often adversely affect somatic growth rates and population abundances. Consequences of introduced North American pumpkinseed Lepomis gibbosus (Linnaeus, 1758) for native $S$. trutta were examined in stream stretches with and without $L$. gibbosus. Data for somatic growth rates and trophic niche breadth (using stable isotope
\end{abstract}

Handling editor: M. Power

M. C. Jackson · J. R. Britton · J. Cucherousset .

Z. Guo · R. E. Gozlan · G. H. Copp

Department of Life and Environmental Sciences, Faculty of Science and Technology, Bournemouth University,

Fern Barrow, Poole, Dorset BH12 5BB, UK

\section{C. Jackson}

Department of Zoology and Entomology, Centre for Invasion Biology, University of Pretoria, Pretoria, Gauteng, South Africa

J. Cucherousset $\cdot$ S. Stakènas · M. G. Godard .

G. H. Copp ( ()

Salmon \& Freshwater Team, Centre for Environment, Fisheries \& Aquaculture Science, Pakefield Road, Lowestoft, Suffolk NR33 OHT, UK

e-mail: gordon.copp@cefas.co.uk

J. Cucherousset

CNRS, ENFA, UMR 5174 EDB (Laboratoire Évolution \& Diversité Biologique), Université Paul Sabatier, 118 route de Narbonne, 31062 Toulouse, France analyses) provided little evidence of $L$. gibbosus presence being detrimental for $S$. trutta. Shifts in $S$. trutta diet at all sites were associated with increased piscivory with increasing body length, with no evidence to suggest that interspecific resource competition with L. gibbosus structured the food web or affected trophic positions. Three years later, and following $L$. gibbosus removal, data revealed slight shifts in the food web at each site, but these related to shifts in resources at the bottom of the food chain rather than a response to $L$. gibbosus removal. Consequently, the ecological consequences of

\author{
Z. Guo \\ Key Laboratory of Tropical Marine Bio-resources and \\ Ecology, South China Sea Institute of Oceanology, \\ Chinese Academy of Sciences, Guangzhou 510301, China \\ S. Stakenas \\ Department of Freshwater Ecology, Institute of Ecology \\ of Vilnius University, Akademijos 2, 08412 Vilnius, \\ Lithuania \\ Present Address: \\ R. E. Gozlan \\ Unité Mixte de Recherche Biologie des Organismes et \\ Écosystèmes Aquatiques (IRD 207, CNRS 7208, MNHN, \\ UPMC), Muséum National d'Histoire Naturelle, Paris Cedex, \\ France \\ M. G. Godard \\ AECOM, 50 Sportsworld Crossing Road, Unit 290, \\ Kitchener, ON N2P 0A4, Canada
}


L. gibbosus for $S$. trutta in the study stream were minimal, with $S$. trutta populations responding more to natural mechanisms regulating their populations than to the presence of this non-native fish species.

Keywords Stable isotope analysis - Alien species . Environmental impacts · Introduced species · Circular statistics $\cdot$ Ecological consequences $\cdot$ Small streams

\section{Introduction}

Freshwater ecosystems often have high rates of introductions of non-native fishes arising from both intentional and accidental releases of species that are associated with, for example, fishery enhancement and the release of unwanted ornamental and bait fishes (Cohen \& Carlton, 1998; Copp et al., 2005; Winfield et al., 2011; Jackson \& Grey, 2013). Problems potentially occur when these fish integrate into the community, interact with native species, and increase competition for resources that instigate cascades that result in community- and ecosystem-level impacts (Cucherousset \& Olden, 2011). Indeed, introduced fishes have been shown to alter food-web structure through increased competition for resources (Vander Zanden et al., 1999; Britton et al., 2010a), which disrupts natural habitat integrity via direct trophic links (Witte et al., 1992). However, these impacts are highly context dependent, and the extent to which these potential ecological consequences are realised is at least partially influenced by the biological and ecological traits of both the native and introduced fishes (Jackson et al., 2015; Paterson et al., 2015).

Brown trout Salmo trutta Linnaeus, 1758, is widely distributed across Europe and their populations are of high ecological, recreational and commercial value. Consequently, $S$. trutta has priority status in areas of its native range (Piccolo, 2011; Filipe et al., 2013), including high conservation designation (e.g. JNCC, 2014). Despite their value and conservation status, native $S$. trutta populations have been exposed to a number of non-native species across their European range with varying outcomes. For example, when in

J.-M. Roussel

INRA, Agrocampus-Ouest, Écologie et Santé des Écosystèmes, 65 rue de St. Brieuc, 35042 Rennes Cedex, France sympatry with introduced brook trout Salvelinus fontinalis (Mitchill, 1814), high dietary overlap occurs (Cucherousset et al., 2007) potentially resulting in reduced $S$. trutta somatic growth rates (Korsu et al., 2009). In those parts of Europe where European minnow Phoxinus phoxinus (Linnaeus, 1758) has been introduced and become invasive, competition for food resources with $S$. trutta can result in substantial reductions in $S$. trutta population abundances and somatic growth rates (Museth et al., 2007, 2010; Borgstrøm et al., 2010). By contrast, when exposed to non-indigenous amphipods, population abundances of S. trutta can increase via enhanced food availability (Kelly \& Dick, 2005). This emphasises that the consequences of invasions for S. trutta depend upon local factors such as the specific invading species and the structural and functional character of the invaded ecosystem.

The North American centrarchid, pumpkinseed Lepomis gibbosus (Linnaeus, 1758), is a small-bodied, warm-water fish that was introduced into Europe in the late 19th Century for both ornamental and sport fishing purposes, with populations now established in at least 28 countries across Eurasia (Copp \& Fox, 2007). An omnivorous species (García-Berthou \& MorenoAmich, 2000), L. gibbosus inhabits both lentic and lotic environments but most studies have been on pond-dwelling populations (e.g. Copp et al. 2002; Villeneuve et al., 2005; Fox et al., 2011), although studies of stream-dwelling populations also exist (Cucherousset et al., 2009; Fobert et al., 2013; Almeida et al., 2014). Investigations of stream-dwelling populations in England have focused on the expression of their life-history traits, habitat use and dispersal (Stakénas et al., 2009; Vilizzi et al., 2012; Fobert et al., 2013), with recent research in Iberia examining interspecific aggression (Almeida et al., 2014). Thus, there is limited information on their feeding interactions with, and consequences for, native fishes such as $S$. trutta. Initial habitat studies in two tributaries of the River Ouse (Sussex, England) suggested a potential association (or interaction) between native $S$. trutta and non-native $L$. gibbosus (Klaar et al., 2004). Subsequent telemetry studies at the microhabitat scale revealed the two species to exploit different parts of pools (Vilizzi et al., 2012), the preferred stream mesohabitats of both species (Stakenas et al., 2013). Despite this repartition of spatial resources, there remains a potential adverse 
impact on the growth or trophic position of $S$. trutta from invasions of smaller-bodied fishes (Borgstrøm et al., 2010; Museth et al., 2010). Therefore, the aim of the present study was to assess the consequences of introduced L. gibbosus for S. trutta somatic growth rates, diet and trophic relationships and discuss their conservation implications.

\section{Materials and methods}

Study sites and sample collection

The study sites were in Batts Bridge Stream, a small tributary of the Sussex Ouse in Southern England that passes through a number of small, man-made instream reservoirs before its confluence with the main river (Copp et al., 2010). There is no evidence to suggest L. gibbosus breed in the Sussex Ouse catchment (Villeneuve et al., 2005; Copp et al., 2010), and their presence in Batts Stream has been shown (Fobert et al., 2013) to result from escapees from established L. gibbosus populations in floodplain ponds and instream reservoirs (Klaar et al., 2004; Copp \& Fox, 2007). This dispersal into the stream system is associated with extreme flood/spate events (Fobert et al., 2013), with the stream-dwelling L. gibbosus achieving up to seven years of age, elevated lengths at maturity and low gonado-somatic index values (Villeneuve et al., 2005). The present trophic study took place at three stream sites (all three of $200 \mathrm{~m}$ length) in July 2007, two stretches in which $S$. trutta and $L$. gibbosus were sympatric in high (site A) and low (site B) densities and a third (site C) where the species was not observed during any of several surveys between August 2001 (Klaar et al., 2004) and July 2010 (Copp et al., 2010) except a single specimen in November 2004. Under the UK's 'The Prohibition of Keeping or Release of Live Fish (Specified Species) Order 1998', it is illegal to return regulated fish species to open waters. Therefore, with the exception of studies involving fish tagging techniques for which derogations were received (i.e. Fobert et al., 2013; Stakenas et al., 2013), all L. gibbosus captured during surveys prior to 2010 were retained for laboratory analysis. This constituted an on-going removal programme, with successful extirpation of L. gibbosus from the stream assumed to have taken place in July 2007 because L. gibbosus was not captured at any of the sites after that survey, including the single-run survey of site A in October 2009 (Table 1). For the present study, additional data for stable isotope analysis were collected in July 2010 from all sites to match those collected in July 2007.

Fish sampling in July 2007 and 2010 was undertaken using a back-pack electrofishing unit (Bretschneider EFGI 650, Reichenbrnder Strasse 4, D-09224 Chemnitz/Gruna, Germany) whilst moving slowly in an upstream direction. A multiple-run strategy provided depletion estimates (three runs, depending on the depletion rate) that ensured thorough sampling to confirm the absence of L. gibbosus in site C from July 2007 and at all sites from October 2007 onwards. Following their capture, all fish were anaesthetised (MS-222), identified to species level, measured for total length $\left(L_{\mathrm{T}}\right.$; nearest $\left.\mathrm{mm}\right)$, and a pelvic fin clip (L. gibbosus and S. trutta) and scale sample taken (S. trutta only). All procedures were completed under UK Home Office licencing. Upon recovery, and at the conclusion of the sampling, all fish were returned to the river alive except $L$. gibbosus due to their regulation as a non-native species under UK law (cited here above). On the same dates, samples of macro-invertebrates and terrestrial basal resources (grasses and leaves) were also collected.

\section{Somatic growth rates}

The $S$. trutta scales were aged on a projecting microscope ( $\times 48$ magnification). To minimise errors in age estimation, a quality control procedure was utilised as per Musk et al. (2006), and all scales were viewed for an individual fish prior to its age determination. Agreement in ages during the quality control procedure was always above $90 \%$. Following age determination, fish $L_{\mathrm{T}}$ at age was determined for each specimen by back-calculation (scale proportional technique; Francis, 1990), before calculation and testing of the mean standardised growth residuals for each site using two methods (Jones, 2000; Benstead et al., 2007; Storm and Angilletta, 2007) that tested the effect on life-time growth (method 1) and juvenile growth (method 2). To avoid statistical complications from using repeated measurements from individual fish in the same test (i.e. pseudo-replication), in both methods only one $L_{\mathrm{T}}$ per fish was used in each test (Britton et al., 2010a; Beardsley \& Britton, 2012). Method 1 used the back-calculated $L_{\mathrm{T}}$ at the last annulus from each fish, 
Table 1 Density (fish $100 \mathrm{~m}^{-2}$ ) based on data from three depletions in all surveys except in 2009 , which was a single pass (*), whereby the total number of fish captured in all depletions was standardised to the surface area of the stretch (i.e. stretch length $\times$ mean width derived from four measurements at the up- and downstream stop nets and at two transects at equal distances from the stop nets

\begin{tabular}{|c|c|c|c|c|c|c|c|c|c|}
\hline Year & Site & A. anguilla & C. gobio & G. gobio & L. gibbosus & L. planeri & P. fluviatilis & S. trutta & Other \\
\hline August 2001 & A & 0.7 & 0.6 & 7.8 & 8.5 & 0.7 & 0 & 7.8 & 0.3 \\
\hline August 2004 & A & 0 & 41.2 & 9.8 & 38.6 & 0 & 7.7 & 9.8 & 3.9 \\
\hline July 2007 & A & 0.6 & 6.3 & 34.7 & 14.8 & 2.6 & 0 & 4.5 & 0.6 \\
\hline October 2007 & A & 0.2 & 2.2 & 14.2 & 0 & 3.0 & 0 & 2.4 & 7.3 \\
\hline October $2009^{*}$ & A & 0.6 & 16.0 & 44.0 & 0 & 4.2 & 0 & 9.5 & 2.4 \\
\hline July 2010 & A & 0.2 & 4.5 & 25.4 & 0 & 1.2 & 0 & 7.9 & 0 \\
\hline August 2001 & B & 1.1 & 1.9 & 0.3 & 0.9 & 7.4 & 0 & 6.8 & 1.3 \\
\hline August 2004 & B & 0.3 & 17.2 & 5.7 & 0.6 & 0.6 & 4.6 & 4.3 & 0.6 \\
\hline July 2007 & B & 0.5 & 14.2 & 0.2 & 21.5 & 16.3 & 0.7 & 4.9 & 0 \\
\hline October 2007 & B & 0 & 2.8 & 0.0 & 0 & 8.9 & 0.0 & 8.4 & 0 \\
\hline July 2010 & B & 0 & 12.1 & 0.9 & 0 & 1.4 & 1.4 & 6.3 & 0.2 \\
\hline August 2001 & $\mathrm{C}$ & 0.4 & 36.1 & 1.6 & 0 & 0.2 & 0.2 & 7.4 & 2.2 \\
\hline August 2004 & $\mathrm{C}$ & 0.7 & 10.6 & 1.1 & 0.2 & 16.0 & 1.7 & 4.1 & 0.2 \\
\hline July 2007 & $\mathrm{C}$ & 0.6 & 71.6 & 0 & 0 & 11.9 & 1.5 & 6.7 & 0 \\
\hline October 2007 & $\mathrm{C}$ & 0.6 & 71.6 & 0 & 0 & 35.2 & 1.9 & 10.1 & 0.6 \\
\hline July 2010 & $\mathrm{C}$ & 0.6 & 26.2 & 0 & 0 & 3.8 & 0 & 5.2 & 0.8 \\
\hline
\end{tabular}

The category 'Other' species includes infrequently encountered fishes: common bream Abramis brama, chub Leuciscus cephalus, goldfish Carassius auratus, European minnow Phoxinus phoxinus, northern pike Esox lucius, roach Rutilus rutilus, rudd Scardinius erythrophthalmus, stone loach Barbatula barbatula and rainbow trout Oncorhynchus mykiss. The values for 2001 and 2004 are derived from re-analysis of the raw data used in Klaar et al. (2004) and Copp et al. (2010)

using these to determine the mean $L_{\mathrm{T}}$ at each age for all sites using the log-log quadratic function of Vilizzi \& Walker (1999), who identified this as the most precise and biologically meaningful growth model of five quadratic functions and the von Bertalanffy growth model. These values then enabled the standardised residual of the $L_{\mathrm{T}}$ at age of each fish at each site to be calculated (Britton et al., 2010a; Beardsley \& Britton, 2012), with these then tested between the sites using ANOVA with Tukey's post hoc tests. Method 2 used a similar technique, except that the data tested were the back-calculated $L_{\mathrm{T}}$ at age 1 year for each fish, with their standardised residuals calculated from the mean $L_{\mathrm{T}}$ at age 1 for all sites. The effect of age at capture on $L_{\mathrm{T}}$ at age 1 was tested before differences in the standardised residuals between the sites were tested using ANOVA with Tukey's post hoc tests.

Stable isotope analysis

Fish diet composition and trophic niche breadth were quantified using the stable isotope analyses of carbon and nitrogen, as carbon isotopes reflect energy origin with typical enrichment of $0-1 \%$, whereas nitrogen isotopes indicate trophic position and show greater enrichment of 2-4\%o from resource to consumer (Post, 2002; Grey, 2006). All samples for stable isotope analysis (fish fin-clips, macro-invertebrates and terrestrial basal resources) were dried at $60^{\circ} \mathrm{C}$ for $48 \mathrm{~h}$ before being processed at the Stable Isotopes In Nature Laboratory (SINLAB). The stable isotope ratios were expressed as per mille (\%o) using the delta notation $(\delta)$.

Differences in the stable isotope data and trophic niche of L. gibbosus and S. trutta were tested initially by quantifying the differences in $\delta^{13} \mathrm{C}$ and $\delta^{15} \mathrm{~N}$ in July 2007 between the species using analyses of variance (ANOVAs). Variation in $\delta^{13} \mathrm{C}$ and $\delta^{15} \mathrm{~N}$ of $S$. trutta between years was subsequently tested using analyses of covariance (ANCOVAs), with $L_{\mathrm{T}}$ as a covariate. The $\delta^{13} \mathrm{C}$ and $\delta^{15} \mathrm{~N}$ values of both species were then used to calculate their standard ellipse areas $\left(\mathrm{SEA}_{\mathrm{c}}\right)$, a bivariate estimate of the core isotopic trophic niche based on the distribution of individuals in the isotopic space (Jackson et al., 2011, 2012), for each year and 
site. This was completed using the SIAR package in $\mathrm{R}$ (R Core Team, 2013). The subscript 'c' indicates that a small sample size correction was used to increase the accuracy of the trophic niche estimate (Jackson et al., 2011). The extent to which the trophic niche overlapped in $\mathrm{SEA}_{\mathrm{c}}$ between L. gibbosus and S. trutta at sites A and B in July 2007 was also quantified by calculating the bivariate area shared by both species in isotopic space and the proportion (\%) of each species' core niche included in the shared area (Jackson et al., 2011, 2012).

To identify whether there was any consequence of L. gibbosus presence and absence (in July 2007 and July 2010, respectively) on food web structure at sites A and B, circular statistics (Wantzen et al., 2002; Schmidt et al., 2007) were performed (using Oriana 3.0; Rockware, Inc., Golden, Colorado, USA). In contrast to conventional statistical approaches, circular statistics allow the overall change in the bivariate isotopic composition (i.e. $\delta^{13} \mathrm{C}$ and $\delta^{15} \mathrm{~N}$ ) of two groups to be calculated and tested for non-uniformity (Schmidt et al., 2007; Bartels et al., 2012). We grouped populations as four invertebrate functional groups (detritivores [Chironomidae, Ephemeridae], grazers [Plecoptera, Nemouridae], shredders [Gammaridae, Limnephilidae]) and filterers [Simuliidae]) and three native fish species ( $S$. trutta, Cottus gobio Linnaeus, 1758, Lampetra planeri Bloch, 1784). The magnitude and direction (angle) of change in the isotopic composition of each group at each site were calculated between July 2007 (before removal) and July 2010 (after removal-i.e. the last of three consecutive surveys at site A that showed L. gibbosus to have been extirpated), using mean $\delta^{13} \mathrm{C}$ and $\delta^{15} \mathrm{~N}$ values as coordinates (Batschelet, 1981; Schmidt et al., 2007). The magnitude of change was measured as the distance between the two points in $\delta^{13} \mathrm{C}$ and $\delta^{15} \mathrm{~N}$ two-dimensional space, where the two points refer to the same population in July 2007 and in July 2010. The angle of change (from $0^{\circ}$ to $360^{\circ}$ ) was then calculated as the clock-wise direction of this change in bivariate space. Rayleigh's test for circular uniformity assessed whether the directional change departed nonrandomly from uniformity at each site (i.e. whether mean angular change in the isotopic composition of stream populations between July 2007 and July 2010 was non-random; Batschelet, 1981; Schmidt et al., 2007). If non-uniformity was detected, then a Watson-
Williams test was used to test for differences in directional change between sites.

\section{Results}

Abundance, lengths and somatic growth rates

L. gibbosus were only present at sites A and B until July 2007 (Table 1), whereas $S$. trutta was present at all three sites in both years and in higher densities at sites A and B in July 2010 relative to July 2007 (Table 1). Maximum $L_{\mathrm{T}}$ of $S$. trutta remained largely unchanged at all three sites (Table 2), but the minimum $L_{\mathrm{T}}$ at capture in July 2010 was lower at the two sites (A, B), where L. gibbosus were present in July 2007 but no longer in 2010. Age data from July 2007 revealed that the maximum estimated age of $S$. trutta was $3+$ years at site A and $4+$ years at site B and C. There were no significant differences in the life-time growth of $S$. trutta between any of the sites in the July 2007 samples $\left(F_{2,92}=0.34, P>0.05\right.$; mean difference $\pm \mathrm{SE} ; \quad \mathrm{A}-\mathrm{B}: 0.22 \pm 0.28, \quad P>0.05 ; \quad \mathrm{A}-\mathrm{C}$ : $0.13 \pm 0.28, \quad P>0.05 ; \quad$ B-C: $\quad 0.10 \pm 0.28$, $P>0.05)$. For their $L_{\mathrm{T}}$ at age 1 (i.e. juvenile growth), there was no relationship between age at capture and $L_{\mathrm{T}}$ at age 1 (linear regression: $r^{2}=0.01 ; F_{1,93}=0.69$, $P>0.05)$ and so age at capture was not used as a covariate in subsequent tests. These revealed that there were also no significant differences between juvenile

Table 2 Minimum and maximum of fish total length $\left(L_{\mathrm{T}}\right.$, in $\mathrm{mm})$ and standard ellipse areas $\left(S E A_{\mathrm{c}}\right)$ for Salmo trutta and Lepomis gibbosus at each study stretch in July 2007 and July 2010. Number in parentheses indicates the number of individuals analysed for stable isotopes

\begin{tabular}{lllll}
\hline Site & Population & Year & $L_{\mathrm{T}}(\min -\max )$ & SEA $_{\mathrm{c}}\left(\%^{2}\right)$ \\
\hline A & S. trutta & 2007 & $49-311$ & $5.4(n=32)$ \\
& & 2010 & $34-303$ & $4.01(n=27)$ \\
& L. gibbosus & 2007 & $43-121$ & $1.67(n=44)$ \\
& & 2010 & - & - \\
B & S. trutta & 2007 & $70-289$ & $4.53(n=55)$ \\
& & 2010 & $36-286$ & $7.42(n=27)$ \\
& L. gibbosus & 2007 & $52-134$ & $3.01(n=51)$ \\
& & 2010 & - & - \\
C & S. trutta & 2007 & $48-335$ & $3.29(n=45)$ \\
& & 2010 & $45-320$ & $4.18(n=25)$ \\
\hline
\end{tabular}


growth of $S$. trutta at any of the sites in the July 2007 samples $\left(F_{2,92}=2.06, \quad P>0.05 ;\right.$ mean difference $\pm \mathrm{SE} ; \quad \mathrm{A}-\mathrm{B}: \quad 0.31 \pm 0.38, \quad P=0.06 ; \quad \mathrm{A}-\mathrm{C}$ : $0.16 \pm 0.18, P>0.05$; B-C: $0.15 \pm 0.21, P>0.05$.

Trophic ecology

In July 2007, the $\delta^{15} \mathrm{~N}$ and $\delta^{13} \mathrm{C}$ values of L. gibbosus (Fig. 2) were significantly different from $S$. trutta in sites $\mathrm{A}$ and $\mathrm{B}$ ( site A, $\delta^{15} \mathrm{~N}: F_{1,74}=22.62, P<0.001$; $\delta^{13} \mathrm{C}: F_{1,74}=4.76, P=0.03$; site $\mathrm{B}, \delta^{15} \mathrm{~N}: F_{1,104}=$ 75.10; $\left.P<0.001, \delta^{13} \mathrm{C}: F_{1,104}=77.69, P<0.001\right)$. The trophic niche breadth $\left(\mathrm{SEA}_{\mathrm{c}}\right)$ of $L$. gibbosus overlapped that of S. trutta by $4.7 \%$ (site A) and $0 \%$ (site B) in July 2007, with S. trutta occupying a larger trophic niche than L. gibbosus (Fig. 1; Table 2). In July 2007, the $\delta^{13} \mathrm{C}$ of $S$. trutta increased significantly with $L_{\mathrm{T}}$ at sites $\mathrm{A}\left(F_{1,55}=139.6, P<0.001\right)$, B $\left(F_{1,78}=104.6, P<0.001\right)$ and $\mathrm{C}\left(F_{1,66}=157.1\right.$, $P<0.001$ ), with this also apparent in 2010 (A, $F_{1,55}=0.72, P=0.4 ; \mathrm{B}, F_{1,78}=0.07, P=0.79$; C, $F_{1,66}=3.09, P=0.08$; Fig. 2). This indicates an ontogenetic diet towards discovery since fish resources had higher carbon signatures than invertebrate resources across all sites (Table 3 ).

The shift in each stream community's isotopic composition (and therefore food web structure) between July 2007 and July 2010 did not differ significantly among the sites (Fig. 3) and did not vary from uniformity (Rayleigh tests: $P>0.05$ ), with the exception of site A (Rayleigh test: $P=0.02$ ). The shifts in basal resource (tree leaves) and stream population (invertebrates, fish) isotope signatures at site $\mathrm{A}$ were in the same direction (i.e. carbon depletion; Tables 2,3), indicating the observed directional change at site A resulted from a natural isotopic shift in basal resources, rather than being related to the removal of $L$. gibbosus.

\section{Discussion}

Empirical evidence indicates that non-native fishes can have damaging consequences for native fishes and communities as a result of trophic interactions (Baxter et al., 2004; Munawar et al., 2005, Cucherousset \& Olden, 2011), including native populations of $S$. trutta (Museth et al., 2007, 2010; Borgstrøm et al., 2010). The present study, however, suggests that there were minimal influences of non-native $L$. gibbosus on native $S$. trutta somatic growth rates (juvenile and life-time) and trophic position in a stream in Southern England. Although the study had low replication, using only two invaded sites and one un-invaded site, these outputs were supported by the results obtained following the removal of $L$. gibbous and by data from previous studies of habitat use in which S. trutta and L. gibbosus in the upstream stretch (site A) of the stream were found to occupy different parts of (i.e. microhabitat repartition) the pool mesohabitats preferred by both species (Vilizzi et al., 2012; Stakenas et al., 2013). In combination, these outputs indicate patterns of both habitat and resource partitioning between the species. Consequently, from a conservation perspective, our results suggest minimal impact by non-native L. gibbosus on the population status of $S$. trutta in streams in Southern England, and as such there is currently little requirement for subsequent management actions to minimise their ecological interactions. However, recent studies in the same stream system have demonstrated that extreme hydrological events (floods, spates), such as predicted for future climatic conditions (Jenkins et al., 2009), could enable L. gibbosus to establish new pond populations readily (Fobert et al., 2013).

Stable isotope analysis is a popular tool in invasion studies (e.g. Jackson et al., 2012; Sagouis et al., 2015), and here we have shown that it can be valuable in predicting whether or not an invader of stream ecosystems will impact co-existing natives. We found that there was negligible niche overlap between $S$. trutta and L. gibbosus, with no change in S. trutta growth in the presence and absence of the invader, which indicates that stable isotope estimates of niche overlap can be used to predict potential competition and impacts. We also found that the S. trutta populations had a larger dietary breadth than L. gibbosus through their significant ontogenetic trophic shift, which resulted in increased piscivory with increasing body size. That this was related to ontogeny and evident in all sites and in the presence and absence of L. gibbosus was important, as other studies have suggested that natural ontogenetic diet shifts in native fishes can change following the introduction of an invasive species. For example, the invasion by common carp Cyprinus carpio Linnaeus (1758) was indirectly responsible for the gradual decline of sizestructured diet in largemouth bass Micropterus salmoides (Lacepède, 1802) in Lake Naivasha, Kenya, 
Fig. 1 Stable isotope values $\left(\delta^{15} \mathrm{~N}\right.$ and $\delta^{13} \mathrm{C}$ in \%o) of Salmo trutta (black) and Lepomis gibbosus (grey) at sites A, B and C. Data points represent individual fish sampled in July 2007 (open circles) and July 2010 (closed circles). Ellipses represent the standard ellipse area of each population in July 2007 (solid lines) and July 2010 (dashed lines)
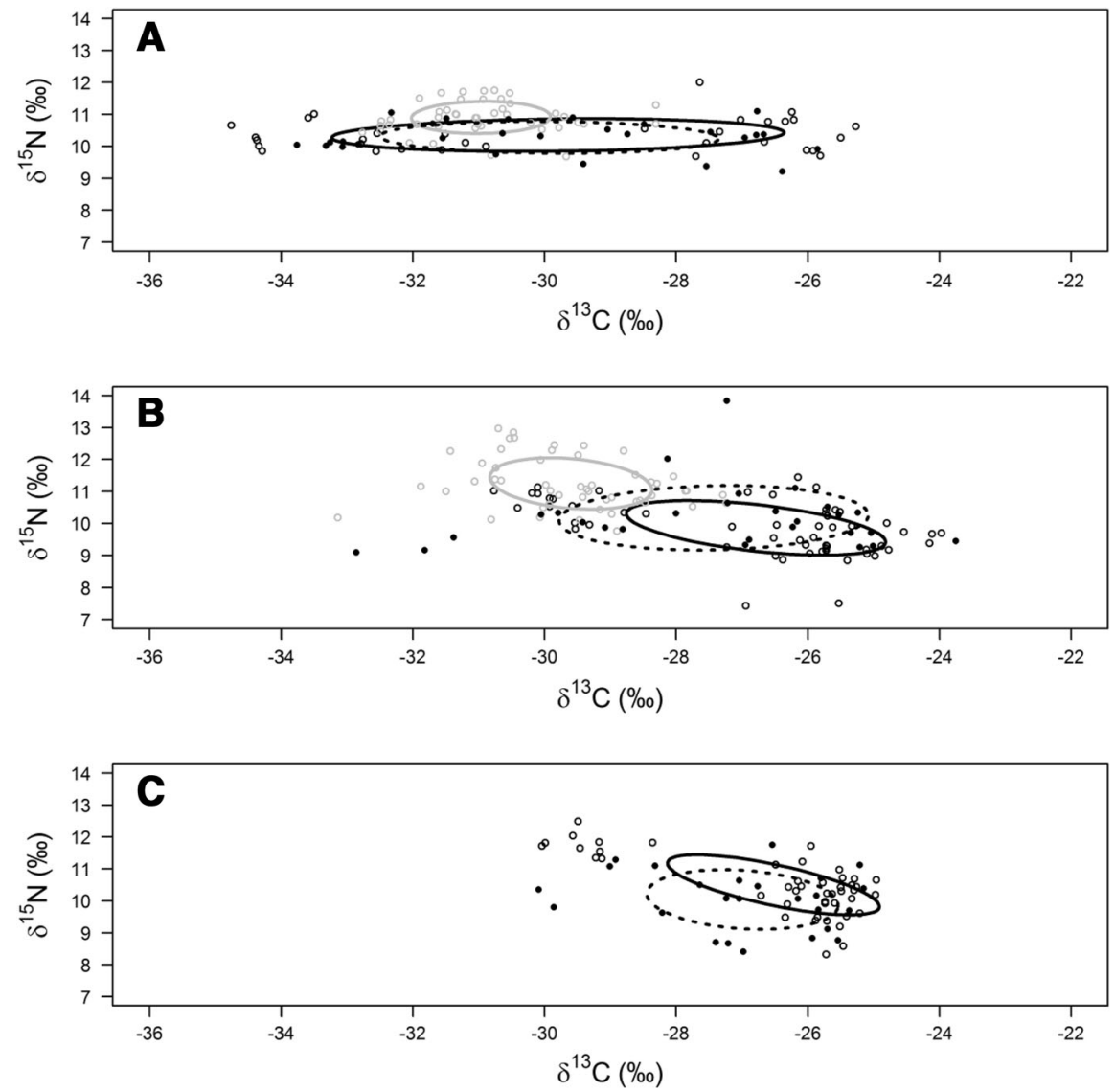

because of its impact on water clarity (Britton et al., 2010b). Such changes were not, however, detected in the present study and this may relate to the fact that $L$. gibbosus currently is not currently invasive in England (Cucherousset et al., 2009) and, as such, their presence might not be sufficient to exert a long-term shift in stream community structure. Invasive species differ from non-native species by having an impact on the recipient ecosystem, which currently has not been demonstrated for L. gibbosus in England. This conclusion is supported by our food-web results, which also indicated minimal ecological consequences arising from L. gibbosus presence. Instead, shifts in the food web between July 2007 and July 2010 resulted from shifts in the baseline resources that were independent of L. gibbosus presence or absence.

In other parts of its European range, such as Spain and Portugal (Godinho et al., 1997), evidence suggests that L. gibbosus is mainly invasive in disturbed, lentic parts of river systems (Mesquita et al., 2006; Almeida et al.,
2009), where it can impact on community structure (Angeler et al., 2002; Prenda-Marin et al., 2003). Similarly, in the Netherlands, in ponds invaded by $L$. gibbosus, impacts on the composition of macro-invertebrate assemblages have also been reported (Van Kleef et al., 2008); however, the L. gibbosus invasion of these ponds followed intensive rehabilitation work (dredging) to favour native plant species, so the invader was again benefiting from environmental disturbance (Ross, 1991; Almeida et al., 2009). That such impacts were not detected in the present study may be for two reasons. Firstly, L. gibbosus has yet to establish self-sustaining populations in U.K. water courses (Cucherousset et al., 2009), which contrasts to Southern Europe, where invasive populations inhabit both lotic and lentic environments and in both cases they are characterised by faster juvenile growth and earlier maturity, thus enhancing recruitment and as a consequence the potential for detrimental effects on the surrounding ecosystem (Fox et al., 2007). Whilst currently non- 


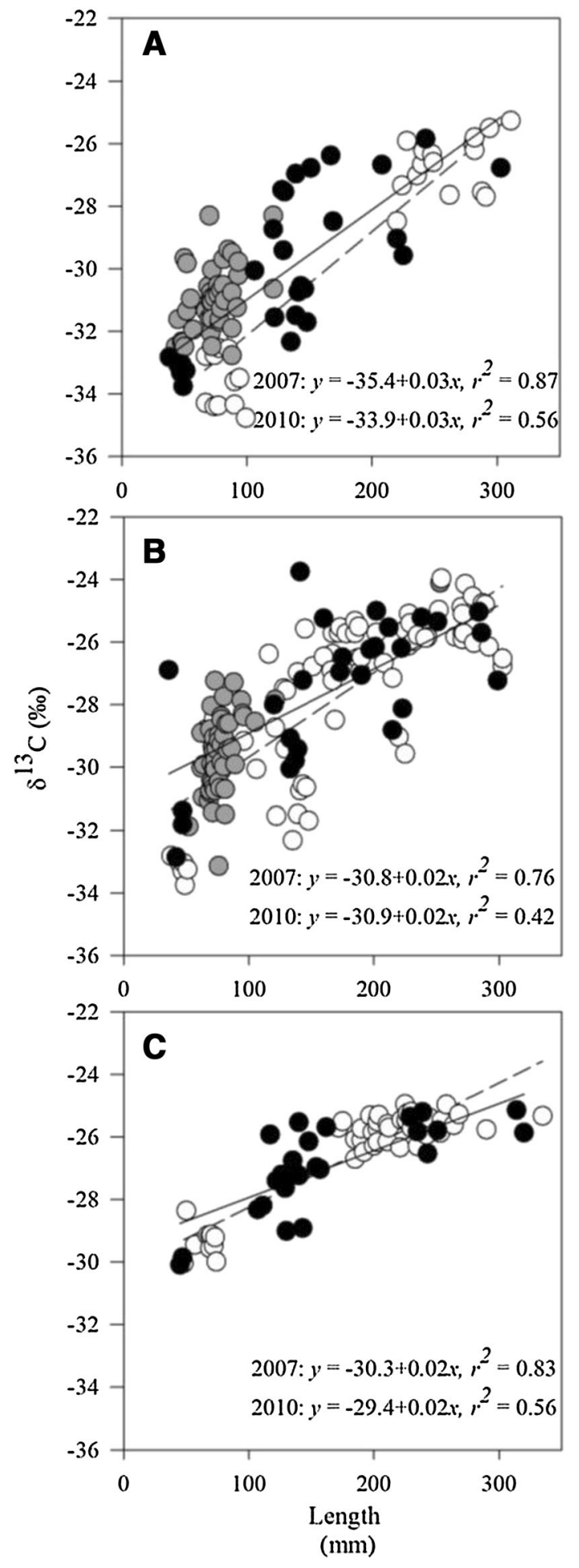

invasive in the U.K., L. gibbosus has been predicted to benefit from warmer future temperatures predicted under conditions of climate change (Britton et al.,
४Fig. 2 Relationship between total length (mm, grey: Lepomis gibbosus, white: Salmo trutta in July 2007 and black: S. trutta in July 2010) and $\delta^{13} \mathbf{C}$ at sites A, B and C. Regression lines are shown for trout in 2007 (dashed) and 2010 (solid)

2010c), with likely increases in dispersal via fluvial environments (Fobert et al., 2013), and this has been supported by field-based experiments of spawning and recruitment (Zięba et al., 2010; Zięba et al., 2015). Further, with increasing temperatures, which are closer to the optimum of L. gibbosus, their impact on the recipient community is likely to be more pronounced (Rahel and Olden, 2008). Thus, the negligible impact recorded in the present study might change in future scenarios. Secondly, most of the documented negative effects of L. gibbosus in its invasive range in Europe has been in lentic systems (Cucherousset et al., 2009), with only one recent in situ stream study, which revealed adverse (aggressive) impacts by L. gibbosus on native fishes (Almeida et al., 2014) — this contrasts our study system in which habitat and resource partitioning is more apparent (Vilizzi et al., 2012; Stakènas et al., 2013). We suggest that similar negative ecological consequences, as observed in Iberia and the Netherlands, may be discovered in future studies of ponds invaded by L. gibbosus in England, as that is where the densest populations of L. gibbosus are found in the U.K. (Fox et al., 2011), especially where these have been recently disturbed (Ross, 1991; Van Kleef et al., 2008).

There is a preponderance of literature in which adverse ecological impacts on native species, including S. trutta (Museth et al., 2007, 2010; Borgstrøm et al., 2010), are attributed to non-native fishes (Vitule et al., 2009; Gozlan et al., 2010; Cucherousset \& Olden 2011) due to increased predation and/or competition, habitat modifications and interactions resulting in interference, e.g. hybridisation, aggression (García-Berthou 2007; Gozlan et al., 2010; Cucherousset \& Olden 2011; Almeida et al., 2014). It is therefore important to report on cases where the effects of a non-native fishes are negligible or at least relatively benign (e.g. Fobert et al., 2011), especially in relation to prioritising the non-native species for management actions (Britton et al., 2011). Moreover, Hansen et al. (2013) suggest that there are generally few differences between the abundances of non-native and native species within invaded habitats, with ecological impacts often associated with speciesspecific relationships between abundance and impact 
Table 3 Mean

stable isotope values $( \pm \mathrm{SE}$; $n$ given in Table 2) of Lepomis gibbosus and the three Salmo trutta size classes $(S t r)$, as well as the resources $(n=3-6$ for each) per site and per year, including Cottus gobio and Lampetra planeri

\begin{tabular}{|c|c|c|c|c|c|}
\hline \multirow[t]{2}{*}{ Site } & \multirow{2}{*}{$\begin{array}{l}\text { Species/ } \\
\text { resource }\end{array}$} & \multicolumn{2}{|l|}{ July 2007} & \multicolumn{2}{|l|}{ July 2010} \\
\hline & & $\delta^{15} \mathrm{~N}(\%)$ & $\delta^{13} \mathrm{C}(\%)$ & $\delta^{15} \mathrm{~N}(\%)$ & $\delta^{13} \mathrm{C}(\% 0)$ \\
\hline \multirow[t]{12}{*}{ A } & L. gibbosus & $10.9 \pm 0.10$ & $-30.97 \pm 0.16$ & - & - \\
\hline & Small $S t r$ & $10.2 \pm 0.10$ & $-33.0 \pm 0.32$ & $10.1 \pm 0.00$ & $-3.6 \pm 0.10$ \\
\hline & Medium $S t r$ & - & - & $10.3 \pm 0.10$ & $-29.7 \pm 0.50$ \\
\hline & Large $S t r$ & $10.5 \pm 0.10$ & $-26.60 \pm 0.23$ & $10.6 \pm 0.20$ & $-27.9 \pm 0.70$ \\
\hline & C. gobio & $11.6 \pm 0.60$ & $-30.1 \pm 0.40$ & $12.1 \pm 0.09$ & $-30.9 \pm 0.20$ \\
\hline & L. planeri & $6.5 \pm 0.20$ & $-27.3 \pm 0.40$ & $6.9 \pm 0.20$ & $-29.9 \pm 0.50$ \\
\hline & Detritivore & $7.9 \pm 1.00$ & $-31.4 \pm 1.10$ & $8.8 \pm 0.60$ & $-33.6 \pm 0.20$ \\
\hline & Filterer & $8.5 \pm 0.04$ & $-35.6 \pm 0.20$ & $7.8 \pm 0.10$ & $-36.0 \pm 0.10$ \\
\hline & Grazer & $7.1 \pm 0.40$ & $-33.0 \pm 0.01$ & $8.1 \pm 0.60$ & $-34.6 \pm 0.70$ \\
\hline & Shredder & $6.7 \pm 0.20$ & $-31.6 \pm 0.30$ & $7.2 \pm 0.10$ & $-31.7 \pm 0.50$ \\
\hline & Grass & $0.2 \pm 0.20$ & $-33.7 \pm 0.10$ & $-0.8 \pm 0.10$ & $-33.0 \pm 0.10$ \\
\hline & Tree leaf & $0.08 \pm 0.4$ & $-28.7 \pm 0.80$ & $-0.8 \pm 0.04$ & $-31.7 \pm 0.50$ \\
\hline \multirow[t]{12}{*}{ B } & L. gibbosus & $10.9 \pm 0.10$ & $-31.0 \pm 0.20$ & - & - \\
\hline & Small $S t r$ & $10.6 \pm 0.10$ & $-29.7 \pm 0.20$ & $9.3 \pm 0.10$ & $-31.1 \pm 1.30$ \\
\hline & Medium $S t r$ & $9.4 \pm 0.30$ & $-26.1 \pm 0.20$ & $10.1 \pm 0.10$ & $-27.0 \pm 0.60$ \\
\hline & Large $S t r$ & $9.7 \pm 0.10$ & $-25.4 \pm 0.20$ & $10.5 \pm 0.40$ & $-26.5 \pm 0.40$ \\
\hline & C. gobio & $11.4 \pm 0.04$ & $-29.7 \pm 0.50$ & $10.9 \pm 0.30$ & $-29.7 \pm 1.00$ \\
\hline & L. planeri & $7.4 \pm 0.50$ & $-28.1 \pm 0.10$ & $7.3 \pm 0.04$ & $-27.01 \pm 0.20$ \\
\hline & Detritivore & $9.7 \pm 0.01$ & $-32.6 \pm 0.01$ & $8.1 \pm 0.70$ & $-31.4 \pm 1.00$ \\
\hline & Filterer & $6.3 \pm 0.01$ & $-37.0 \pm 0.01$ & $6.9 \pm 0.03$ & $-31.9 \pm 0.20$ \\
\hline & Grazer & $8.1 \pm 0.10$ & $-32.2 \pm 0.20$ & $6.6 \pm 0.20$ & $-37.4 \pm 0.70$ \\
\hline & Shredder & $6.7 \pm 0.10$ & $-30.2 \pm 0.10$ & $5.8 \pm 0.20$ & $-29.8 \pm 0.60$ \\
\hline & Grass & $1.2 \pm 0.70$ & $-32.2 \pm 0.80$ & $3.5 \pm 0.10$ & $-33.5 \pm 0.01$ \\
\hline & Tree leaf & $-0.1 \pm 0.4$ & $-28.3 \pm 0.60$ & $2.4 \pm 0.1$ & $-30.5 \pm 0.03$ \\
\hline \multirow[t]{12}{*}{$\mathrm{C}$} & L. gibbosus & - & - & - & - \\
\hline & Small $S t r$ & $11.8 \pm 0.11$ & $-29.4 \pm 0.20$ & $10.1 \pm 0.30$ & $-30.3 \pm 0.10$ \\
\hline & Medium $S t r$ & $10.2 \pm 0.20$ & $-26.0 \pm 0.10$ & $9.8 \pm 0.20$ & $-27.5 \pm 0.30$ \\
\hline & Large $S t r$ & $10.1 \pm 0.10$ & $-25.6 \pm 0.10$ & $10.5 \pm 0.30$ & $-25.9 \pm 0.20$ \\
\hline & C. gobio & $10.8 \pm 0.20$ & $-28.2 \pm 0.40$ & $11.3 \pm 0.20$ & $-28.7 \pm 0.40$ \\
\hline & L. planeri & $8.9 \pm 0.20$ & $-26.3 \pm 0.40$ & $7.1 \pm 0.40$ & $-25.4 \pm 1.00$ \\
\hline & Detritivore & $9.2 \pm 0.20$ & $-29.2 \pm 0.40$ & $8.9 \pm 0.20$ & $-29.7 \pm 0.01$ \\
\hline & Filterer & $8.8 \pm 0.20$ & $-30.9 \pm 0.10$ & $7.7 \pm 0.04$ & $-29.5 \pm 0.00$ \\
\hline & Grazer & $11.1 \pm 0.10$ & $-29.5 \pm 0.20$ & $7.6 \pm 0.10$ & $-31.7 \pm 0.40$ \\
\hline & Shredder & $7.7 \pm 0.10$ & $-27.6 \pm 0.02$ & $5.5 \pm 0.30$ & $-28.8 \pm 0.40$ \\
\hline & Grass & $6.9 \pm 0.10$ & $-32.4 \pm 0.20$ & $1.8 \pm 0.40$ & $-30.7 \pm 0.10$ \\
\hline & Tree leaf & $-1.2 \pm 0.20$ & $-28.7 \pm 0.20$ & $1.2 \pm 0.03$ & $-31.9 \pm 0.10$ \\
\hline
\end{tabular}

replication, and there were some inherent differences in body sizes between the fishes that could have been the driver of trophic and habitat partitioning (e.g. O'Farrel et al., 2014), it nevertheless provides a strong case study, which highlights an observed pattern that the consequences of non-native species on native species and communities are often relatively benign (Gozlan, 2008). 


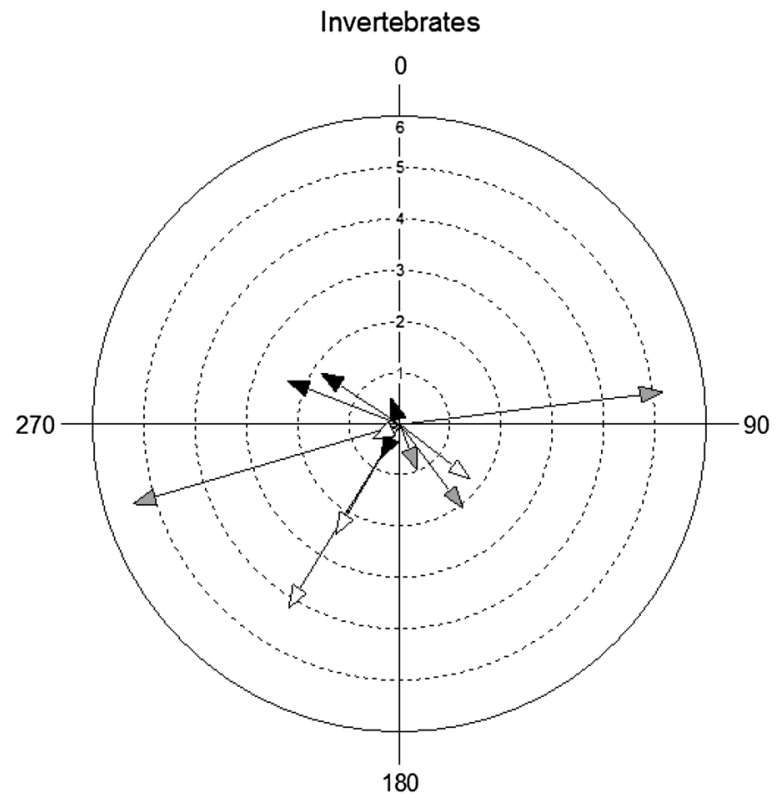

Fig. 3 Arrow diagrams showing the mean change in stable isotope values of invertebrate functional groups and fish between July 2007 and July 2010 at sites A (black), B (grey) and C (white). Each arrow represents a functional feeding group of

Although we argue that the present study reveals that $L$. gibbosus is currently a benign non-native species in U.K. fluvial systems, it has already been outlined that the species' invasion status is not expected to remain static over the longer term. Their apparent invasive characteristics, which have been observed elsewhere in small, disturbed still waters (Van Kleef et al., 2008; Fox et al. 2011), are predicted to express themselves under conditions of climate warming (Britton et al., 2010c; Fobert et al., 2013; Zięba et al., 2015). Thus, whilst there was little evidence that non-native L. gibbosus had any ecological consequences for the native $S$. trutta populations of a stream in southern England, their spread to other systems (e.g. still waters) may have a more severe impact, especially under future scenarios of climate change.

Acknowledgments Conceived within the framework of an international network initiated with a NATO Science Programme 'Collaborative Linkage Grant' (awarded to GHC), this study was funded mainly by a research contract to GHC from the U.K. Department for Environment, Food and Rural Affairs (Defra). Additional support of JC was received via an "ERG Marie Curie"' grant (PERG08-GA-2010-276969) in the lab EDB, part of the Laboratoire d'Excellence (LABEX) entitled TULIP (ANR -10-LABX-41).

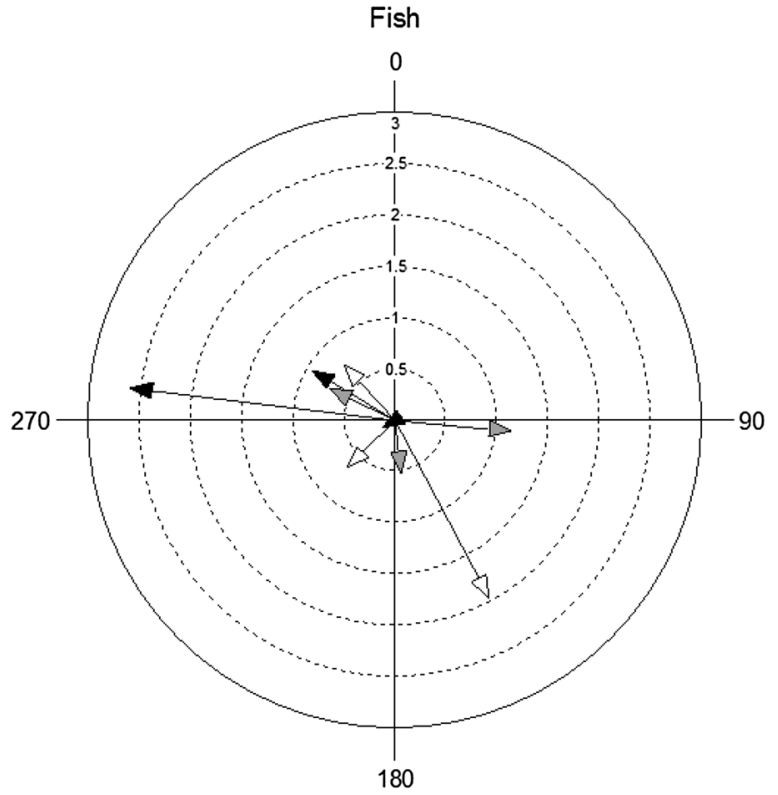

invertebrates or species of fish and shows the direction and magnitude of change in their mean isotope signatures between years

Open Access This article is distributed under the terms of the Creative Commons Attribution 4.0 International License (http:// creativecommons.org/licenses/by/4.0/), which permits unrestricted use, distribution, and reproduction in any medium, provided you give appropriate credit to the original author(s) and the source, provide a link to the Creative Commons license, and indicate if changes were made.

\section{References}

Almeida, D., A. Almodóvar, G. G. Nicola \& B. Elvira, 2009. Feeding tactics and body condition of two introduced populations of pumpkinseed Lepomis gibbosus: taking advantages of human disturbances? Ecology of Freshwater Fish 18: 15-23.

Almeida, D., L. Vilizzi \& G. H. Copp, 2014. Interspecific aggressive behaviour of invasive pumpkinseed Lepomis gibbosus in Iberian fresh waters. PLoS One 9: e88038.

Angeler, D. G., M. Álvarez-Cobelas, S. Sánchez-Carrillo \& M. A. Rodrigo, 2002. Assessment of exotic fish impacts on water quality and zooplankton in a degraded semi-arid floodplain wetland. Aquatic Sciences 64: 76-86.

Bartels, P., J. Cucherousset, C. Gudasz, M. Jansson, J. Karlsson, L. Persson, K. Premke, A. Rubach, K. Steger, L. J. Tranvik \& P. Eklov, 2012. Terrestrial subsidies to lake food webs: an experimental approach. Oecologia 168: 807-818.

Batschelet, E., 1981. Circular Statistics in Biology. Academic Press, London: 371. 
Baxter, C. V., K. D. Fausch, M. Murakami \& P. L. Chapman, 2004. Fish invasion restructures stream and forest food webs by interrupting reciprocal prey subsidies. Ecology 85 : 2656-2663.

Beardsley, H. \& J. R. Britton, 2012. Contribution of temperature and nutrient loading to growth rate variation of three cyprinid fishes in a lowland river. Aquatic Ecology 46: 143-152.

Benstead, J. P., A. C. Green, L. A. Deegan, B. J. Peterson, K. Slavik, W. B. Bowden \& A. E. Hershey, 2007. Recovery of three arctic stream reaches from experimental nutrient enrichment. Freshwater Biology 52: 1077-1089.

Borgstrøm, R., J. Museth \& J. E. Brittain, 2010. The brown trout (Salmo trutta) in the lake, Øvre Heimdalsvatn: long-term changes in population dynamics due to exploitation and the invasive species, European minnow (Phoxinus phoxinus). Hydrobiologia 642: 81-91.

Britton, J. R., G. D. Davies \& C. Harrod, 2010a. Trophic interactions and consequent impacts of the invasive fish Pseudorasbora parva in a native aquatic foodweb: a field investigation in the UK. Biological Invasions 12: 1533-1542.

Britton, J. R., D. M. Harper, D. O. Oyugi \& J. Grey, 2010b. The introduced Micropterus salmoides in an equatorial lake: a paradoxical loser in an invasion meltdown scenario? Biological Invasions 12: 3439-3448.

Britton, J. R., J. Cucherousset, G. D. Davies, M. J. Godard \& G. H. Copp, 2010c. Non-native fishes and climate change: predicting species responses to warming temperatures in a temperate region. Freshwater Biology 55: 1130-1141.

Britton, J. R., J. Cucherousset, J. Grey \& R. E. Gozlan, 2011. Determining the strength of exploitative competition from an introduced fish: roles of density, biomass and body size. Ecology of Freshwater Fish 20: 74-79.

Cohen, A. N. \& J. T. Carlton, 1998. Accelerating invasion rate in a highly invaded estuary. Science 279: 555.

Copp, G. H. \& M. G. Fox, 2007. Growth and life history traits of introduced pumpkinseed (Lepomis gibbosus) in Europe, and the relevance to its potential invasiveness. In Gherardi, F. (ed.), Freshwater Bioinvaders: Profiles, Distribution, and Threats. Springer, Berlin: 289-306.

Copp, G. H., M. G. Fox \& V. Kováč, 2002. Growth, morphology and life history traits of a coolwater European population of pumpkinseed Lepomis gibbosus. Archiv für Hydrobiologie 155: 585-614.

Copp, G. H., K. J. Wesley \& L. Vilizzi, 2005. Pathways of ornamental and aquarium fish introductions into urban ponds of Epping Forest (London, England): the human vector. Journal of Applied Ichthyology 21: 263-274.

Copp, G. H., S. Stakenas \& J. Cucherousset, 2010. Aliens versus the natives: interactions between introduced pumpkinseed and indigenous brown trout in small streams of Southern England. American Fisheries Society Symposium 73: 347-370.

Cucherousset, J. \& J. D. Olden, 2011. Ecological impacts of nonnative freshwater fishes. Fisheries 36: 215-230.

Cucherousset, J., J. C. Aymes, F. Santoul \& R. Céréghino, 2007. Stable isotope evidence of trophic interactions between introduced brook trout (Salvelinus fontinalis) and native brown trout (Salmo trutta) in a mountain stream of southwest France. Journal of Fish Biology 71: 210-223.
Cucherousset, J., G. H. Copp, M. G. Fox, E. Sterud, H. H. van Kleef, H. Verreycken \& E. Zahorska, 2009. Life-history traits and potential invasiveness of introduced pumpkinseed Lepomis gibbosus populations in northwestern Europe. Biological Invasions 11: 2171-2180.

Filipe, A. F., D. Markovic, F. Pletterbauer, C. Tisseuil, A. De Wever, S. Schmutz, N. Bonada \& J. Freyhof, 2013. Forecasting fish distribution along stream networks: brown trout (Salmo trutta) in Europe. Diversity and Distributions 19: 1059-1071.

Fobert, E., M. G. Fox, M. Ridgway \& G. H. Copp, 2011. Heated competition: How climate change will affect competing non-native pumpkinseed and Eurasian perch in the U.K. Journal of Fish Biology 79: 1592-1607.

Fobert, E., G. Zięba, L. Vilizzi, M. J. Godard, M. G. Fox, S. Stakenas \& G. H. Copp, 2013. Predicting non-native fish dispersal under conditions of climate change: case study in England of dispersal and establishment of pumpkinseed Lepomis gibbosus in a floodplain pond. Ecology of Freshwater Fish 22: 106-116.

Fox, M. G., A. Vila-Gispert \& G. H. Copp, 2007. Life-history traits of introduced Iberian pumpkinseed Lepomis gibbosus relative to native populations. Can differences explain colonization success? Journal of Fish Biology 71: 56-69.

Fox, M. G., F. Villeneuve \& G. H. Copp, 2011. Seasonal reproductive allocation, local-scale variation and environmental influences on life history traits of introduced pumpkinseed (Lepomis gibbosus) in southern England. Fundamental and Applied Limnology 178: 231-243.

Francis, R. I. C. C., 1990. Back-calculation of fish length: a critical review. Journal of Fish Biology 36: 883-902.

García-Berthou, E., 2007. The characteristics of invasive fishes: what has been learned so far? Journal of Fish Biology 71: 33-55.

García-Berthou, E. \& R. Moreno-Amich, 2000. Food of introduced pumpkinseed sunfish: ontogenetic diet shift and seasonal variation. Journal of Fish Biology 57: 29-40.

Godinho, F., M. T. Ferreira \& R. V. Cortes, 1997. The environmental basis of diet variation in pumpkinseed sunfish, Lepomis gibbosus, and largemouth bass, Micropterus salmoides, along an Iberian river basin. Environmental Biology of Fishes 50: 105-115.

Gozlan, R. E., 2008. Introduction of non-native freshwater fish: is it all bad? Fish and Fisheries 9: 106-115.

Gozlan, R. E., J. R. Britton, I. G. Cowx \& G. H. Copp, 2010. Current knowledge on non-native freshwater fish introductions. Journal of Fish Biology 76: 751-786.

Grey, J., 2006. The use of stable isotope analyses in freshwater ecology: current awareness. Polish Journal of Ecology 54: 563-584

Hansen, G. J., M. J. Vander Zanden, M. J. Blum, M. K. Clayton, E. F. Hain, J. Hauxwell, M. Izzo, M. S. Kornis, P. B. McIntrye, A. Mikulyuk, E. Nilsson, J. D. Olden, M. Papes \& S. Sharma, 2013. Commonly rare and rarely common: comparing population abundance of invasive and native aquatic species. PLoS One 8: 77415.

Jackson, M. C. \& J. Grey, 2013. Accelerating rates of freshwater invasions in the catchment of the River Thames. Biological Invasions 15: 945-951.

Jackson, A. L., R. Inger, A. C. Parnell \& S. Bearhop, 2011. Comparing isotopic niche widths among and within 
communities: bayesian analysis of stable isotope data. Journal of Animal Ecology 80: 595-602.

Jackson, M. C., A. L. Jackson, J. R. Britton, I. Donohue, D. M. Harper \& J. Grey, 2012. Population-level metrics of trophic structure based on stable isotopes and their application to invasion ecology. PLoS One 7: e31757.

Jackson, M. C., A. Ruiz Navarro \& J. R. Britton, 2015. Population density modifies the ecological impacts of invasive species. Oikos 124: 880-887.

Jenkins, G. J., J. M. Murphy, D. M. H. Sexton, J. A. Lowe, P. Jones \& C. G. Kilsby, 2009. UK Climate Projections: Briefing report. Met Office Hadley Centre, Exeter, UK. (ISBN 978-1-906360-04-7; http://ukclimateprojections. defra.gov.uk).

JNCC (2014) UK BAP priority fish species (excluding purely marine species). http://jncc.defra.gov.uk/page-5164. Accessed 28/01/2015.

Jones, C. M., 2000. Fitting growth curves to retrospective sizeat-age data. Fisheries Research 46: 123-129.

Kelly, D. W. \& J. T. A. Dick, 2005. Introduction of the nonindigenous amphipod Gammarus pulex alters population dynamics and diet of juvenile trout Salmo trutta. Freshwater Biology 50: 127-140.

Klaar, M., G. H. Copp \& R. Horsfield, 2004. Autumnal habitat use of non-native pumpkinseed Lepomis gibbosus and associations with native fish species in small English streams. Folia Zoologica 53: 189-202.

Korsu, K., A. Huusko \& T. Muotka, 2009. Does the introduced brook trout (Salvelinus fontinalis) affect growth of the native brown trout (Salmo trutta)? Naturwissenschaften 96: 347-353.

Mesquita, N., M. M. Coelho \& M. M. Filomena, 2006. Spatial variation in fish assemblages across small Mediterranean drainages: effects of habitat and landscape context. Environmental Biology of Fishes 77: 105-120.

Munawar, M., I. F. Munawar, N. E. Mandrak, M. Fitzpatfick, R. Dermott \& J. Leach, 2005. An overview of the impact of non-indigenous species on the food web integrity of North American Great Lakes: lake Erie example. Aquatic Ecosystem Health \& Management 8: 375-395.

Museth, J., T. Hesthagen, O. T. Sandlund, E. B. Thorstad \& O. Ugedal, 2007. The history of the minnow Phoxinus phoxinus (L.) in Norway: from harmless species to pest. Journal of Fish Biology 71: 184-195.

Museth, J., R. Borgstrøm \& J. E. Brittain, 2010. Diet overlap between introduced European minnow (Phoxinus phoxinus) and young brown trout (Salmo trutta) in the lake, Øvre Heimdalsvatn: a result of abundant resources or forced niche overlap? Hydrobiologia 643: 93-100.

Musk, R., J. R. Britton \& S. Axford, 2006. The effect of subjective fish scales ageing on growth and recruitment analyses: a case study from the UK. Acta Icthyologica et Piscatoria 36: 81-84.

O'Farrell, S., S. Bearhop, R. A. R McGill, C. P. Dahlgren, D. R. Brumbaugh \& P. J. Mumby, 2014. Habitat and body size effects on the isotopic niche space of invasive lionfish and endangered Nassau grouper. Ecosphere 5: art123. 10.1890/ ES14-00126.1

Paterson, R. A., J. T. Dick, D. W. Pritchard, M. Ennis, M. J. Hatcher \& A. M. Dunn, 2015. Predicting invasive species impacts: a community module functional response approach reveals context dependencies. Journal of Animal Ecology 84: 453-463.

Piccolo, J. J., 2011. Challenges in the conservation, rehabilitation and recovery of native stream salmonid populations: beyond the 2010 Luarca symposium. Ecology of Freshwater Fish 20: 346-351.

Post, D. M., 2002. Using stable isotopes to estimate trophic position: models, methods, and assumptions. Ecology 83: 703-718.

Prenda-Marin, J., F. Blanco \& M. Clavero, 2003. The impact of introduced centrarchids on native fish fauna and otter (Lutra lutra) diet in a Mediterranean river basin. Comptes Rendus de l'Académie des Sciences 326(Supplement 1): 224.

R Development Core Team, 2013. R: A language and environment for statistical computing. R Foundation for Statistical Computing, Vienna. ISBN 3-900051-07-0, URL http://www.R-project.org/.

Rahel, F. J. \& J. D. Olden, 2008. Assessing the effects of climate change on aquatic invasive species. Conservation Biology 22: 521-533.

Ross, S. T., 1991. Mechanisms structuring stream fish assemblages: are there lessons from introduced species? Environmental Biology of Fishes 30: 359-368.

Sagouis, A., J. Cucherousseet, S. Villéger, F. Santoul \& S. Boulêtreau, 2015. Non-native species modify the isotopic structure of freshwater fish communities across the globe. Ecography 38: 979-985.

Schmidt, S. N., J. D. Olden, C. T. Solomon \& M. J. Vander Zanden, 2007. Quantitative approaches to the analysis of stable isotope food web data. Ecology 88: 2793-2802.

Stakenas, S., G. H. Copp \& D. M. Scott, 2009. Tagging effects on three non-native fish species in England (Lepomis gibbosus, Pseudorasbora parva, Sander lucioperca) and of native Salmo trutta. Ecology of Freshwater Fish 18: 167-176.

Stakenas, S., L. Vilizzi \& G. H. Copp, 2013. Habitat use, home range, movements and interactions of introduced Lepomis gibbosus and native Salmo trutta in a small stream of Southern England. Ecology of Freshwater Fish 22: 202-215.

Storm, M. A. \& M. J. Angilletta, 2007. Rapid assimilation of yolk enhances growth and development of lizard embryos from a cold environment. Journal of Experimental Biology 210: 3415-3421.

Vander Zanden, M. J., J. M. Casselman \& J. B. Rasmussen, 1999. Stable isotope evidence for the food web consequences of species invasions in lakes. Nature 401: 464-467.

Van Kleef, H. H., G. van der Velde, R. S. E. Leuven \& H. Esselink, 2008. Pumpkinseed sunfish (Lepomis gibbosus) invasions facilitated by introductions and nature management strongly reduce macroinvertebrate abundance in isolated water bodies. Biological Invasions 10: 1481-1490.

Vilizzi, L. \& K. F. Walker, 1999. Age and growth of the common carp, Cyprinus carpio, in the River Murray, Australia: validation, consistency of age interpretation, and growth models. Environmental Biology of Fishes 54: 77-106.

Vilizzi, L., S. Stakenas \& G. H. Copp, 2012. Use of constrained additive and quadratic ordination in fish habitat studies: an application to introduced pumpkinseed (Lepomis gibbosus) 
and native brown trout (Salmo trutta) in an English stream. Fundamental and Applied Limnology 180: 69-75.

Villeneuve, F., G. H. Copp, M. G. Fox \& S. Stakėnas, 2005. Interpopulation variation in growth and life-history traits of the introduced sunfish, pumpkinseed Lepomis gibbosus, in southern England. Journal of Applied Ichthyology 21: 275-281.

Vitule, J. R., C. A. Freire \& D. Simberloff, 2009. Introduction of non-native freshwater fish can certainly be bad. Fish and Fisheries 10: 98-108.

Wantzen, K. M., F. D. Machado, M. Voss, H. Boriss \& W. J. Junk, 2002. Seasonal isotopic shifts in fish of the Pantanal wetland, Brazil. Aquatic Sciences 64: 239-251.

Winfield, I. J., J. M. Fletcher \& J. B. James, 2011. Invasive fish species in the largest lakes of Scotland, Northern Ireland,
Wales and England: the collective UK experience. Hydrobiologia 660: 93-103.

Witte, F., T. Goldschmidt, J. Wanink, M. Oijen, K. Goudswaard, E. Witte-Maas \& N. Bouton, 1992. The destruction of an endemic species flock: quantitative data on the decline of the haplochromine cichlids of Lake Victoria. Environmental Biology of Fishes 34: 1-28.

Zięba, G., M. G. Fox \& G. H. Copp, 2010. The effect of elevated temperature on spawning frequency and spawning behaviour of introduced pumpkinseed Lepomis gibbosus in Europe. Journal of Fish Biology 77: 1850-1855.

Zięba, G., M. G. Fox \& G. H. Copp, 2015. How will climate change affect non-native pumpkinseed Lepomis gibbosus in the U.K.? PLoS One Biology 10(8): e0135482. 